\title{
Synthesis and Characterization of New Pyrazolopyrimidine Derivatives Incorporated to Benzothiaazole
}

\author{
Mohamed. M. Waly ${ }^{1, * \mathbb{C}}$, Eman H. Tawfik ${ }^{1} \mathbb{D}$, Ahmed A. Fadda ${ }^{1}(\mathbb{D}$ \\ 1 Department of Chemistry, Faculty of Science, Mansoura University, 35516 Mansoura, Egypt \\ * Correspondence: afadda50@yahoo.com;
}

Scopus Author ID 7005134210

Received: 26.10.2020; Revised: 10.01.2021; Accepted: 13.01.2021; Published: 19.01.2021

\begin{abstract}
Reaction of 2-Amino-6-methyl benzothiazole with 1-cyano-acetyl-3,5-dimethylpyrazole afforded cyanoacetamide derivative (2). Compound 2 was used as the precursor for the synthesis of novel aminopyrazole derivative (5) by reaction with phenyl isothiocyanate and methyl iodide followed by addition of hydrazine hydrate. Treatment of aminopyrazole (5) with different reagents gave pyrazolopyrimidine derivatives (7-12). The newly synthesized compounds were characterized by elemental analysis and the use of spectral data (IR, ${ }^{1} \mathrm{H}$ NMR, and MS).
\end{abstract}

Keywords: pyrazolopyrimidine; cyanoacetamide; benzothiazole; aminopyrazole.

(C) 2020 by the authors. This article is an open-access article distributed under the terms and conditions of the Creative Commons Attribution (CC BY) license (https://creativecommons.org/licenses/by/4.0/).

\section{Introduction}

Heterocycles, especially containing sulfur and nitrogen, play an important role in our life in addition to their pharmaceutical properties [1]. Benzothiazole moiety have enticed great attention due to their diverse biological efficacy e.g. anticancer [2], antitubercular [3], antimicrobial [4], anticonvulsant [5], antiviral [6], antimalarial [7], antihelmintic [8], antiproliferative agents [9], analgesic [10], anti-inflammatory [10, 11], antidiabetic [12] and fungicidal activities [13]. Moreover, benzothiazole derivatives have wide use in various research areas, for example, in many industrial fields [14-16].

Cyanoacetamide- $N$-derivatives are considered one of the most important classes as starting material to synthesize heterocyclic compounds $[17,18]$. They are used as starting materials in many synthetic methods, which can react via the cyano and carbonyl groups with bifunctional reagents to afford different classes of heterocyclic compounds. Moreover, a variety of substitution and condensation reactions can occur via the active methylene of these compounds. Cyanoacetamides have various biological activities [19, 20].

Pyrazolopyrimidines, which are known to be purine analog, have received great attention due to their pharmacological activities [21, 22]. They used antischistosomal, antimetabolites in purine biochemical interactions, sedative and antitrypanosomal [23], anxiolytic [24], kinase inhibitors [25], HIV (human immunodeficiency viruses), reverse transcriptase inhibitors [26], and antifungal and antimalarial activities [27].

Due to these important biological activities, we aimed to use benzothiazole cyanoacetamide 2 to synthesize new pyrazolopyrimidine systems and elucidate their structures by IR ${ }^{1} \mathrm{H}$ NMR \& MS spectroscopic techniques. 


\section{Materials and Methods}

All melting points were measured on Gallen Kamp electric melting point apparatus. Thermo Scientific Nicolet iS10 FTIR spectrometer was used for IR spectra. The ${ }^{1} \mathrm{H}-\mathrm{NMR}$ spectra were measured in (DMSO-d6) at $500 \mathrm{MHz}$ on JEOL's NMR spectrometer using tetramethylsilane as an internal standard chemical shift are expressed as $\delta / \mathrm{ppm}$. Mass spectra (EI) were recorded on $70 \mathrm{eV}$ with a Varian MAT 311 A Spectrometer at Al-Azhar University, Cairo, Egypt. Elemental analyses $(\mathrm{C}, \mathrm{H}$, and $\mathrm{N})$ and antimicrobial screening were measured in the regional center for mycology and biochemistry, Al-Azhar University, Cairo, Egypt.

\subsection{Synthesis of 2-cyano-N-(6-methylbenzo[d]thiazol-2-yl)acetamide (2).}

A mixture of 2-Amino-6-methyl benzothiazole (2 mmol) and 1-cyano-acetyl-3,5dimethylpyrazole $(2 \mathrm{mmol})$ in toluene was refluxed for $20 \mathrm{~min}$. The precipitate which formed by cooling was recrystallized from ethanol to afford 2 . Yield $95 \% ; \mathrm{mp} 225-227^{\circ} \mathrm{C}$; IR $(\mathrm{KBr})$ : $\mathrm{v} / \mathrm{cm}^{-1}=3199(\mathrm{NH}), 2262(\mathrm{C} \equiv \mathrm{N}), 1706(\mathrm{C}=\mathrm{O}) ;{ }^{1} \mathrm{H}$ NMR (DMSO-d $): \delta 2.40\left(\mathrm{~s}, 3 \mathrm{H}, \mathrm{CH}_{3}\right), 4.11$ (s, 2H, $\mathrm{CH}_{2}$ ), 7.24-7.77 (m, 3H, ArCH), 12.58 (s, 1H, N-H).MS m/z (\%): $232\left(\mathrm{M}^{+}+1,4.85\right)$, 231 ( $\left.\mathrm{M}^{+}, 16.46\right), 191$ (10.25), 164 (100.00), 136 (19.64), 121 (20.41), 77 (16.66), 68 (56.30). Anal. Calced for $\mathrm{C}_{11} \mathrm{H}_{9} \mathrm{~N}_{3} \mathrm{OS}$ (231.27): C, 57.13; H, 3.92; N, 18.17\%.Found: C, 57.10; H, 3.86; $\mathrm{N}, 18.09 \%$.

\subsection{Synthesis of 2-Cyano-N-(4-hydroxyphenyl)-3-(methylthio)-3-(phenylamino)acrylamide} (4).

Compound $2(2 \mathrm{mmol})$ was added to a solution of potassium hydroxide $(2 \mathrm{mmol})$ in DMF ( $15 \mathrm{~mL})$ and stirred for $30 \mathrm{~min}$, then phenyl isothiocyanate $(2 \mathrm{mmol})$ added to this above mixture. The reaction mixture was stirred for further 6 hours at room temperature then add methyl iodide and stirring for 1 hour more. The reaction mixture was poured onto ice cold water $(100 \mathrm{~mL})$. Filter off the obtained precipitate, dry and recrystallize from the appropriate solvent to afford 4. Yield 89\%; mp 178-180 C; IR (KBr): v/cm ${ }^{-1}=3398(\mathrm{NH}), 2195(\mathrm{C} \equiv \mathrm{N})$, $1630(\mathrm{C}=\mathrm{O}) ;{ }^{1} \mathrm{H}$ NMR (DMSO-d6): $\delta 2.23\left(\mathrm{~s}, 3 \mathrm{H}, \mathrm{CH}_{3}\right), 2.38\left(\mathrm{~s}, 3 \mathrm{H}, \mathrm{CH}_{3}\right), 7.25-7.66(\mathrm{~m}, 8 \mathrm{H}$, Ar H), 12.08 (s, 1H, N-H), 13.40 (s, 1H, N-H).MS m/z (\%): $382\left(\mathrm{M}^{+}+2,13.38\right), 381\left(\mathrm{M}^{+}+1\right.$, 25.57), $380\left(\mathrm{M}^{+}, 100.00\right), 333$ (86.05), 164 (4.43), 77 (10.55). Anal. Calced for $\mathrm{C}_{19} \mathrm{H}_{16} \mathrm{~N}_{4} \mathrm{OS}_{2}$ (380.08): C, 59.98; H, 4.24; N, 14.73\%. Found: C, 59.86; H, 4.20; N, 12.68\%.

2.3. Synthesis of 5-amino-N-(6-methylbenzo[d]thiazol-2-yl)-3-(phenylamino)-1H-pyrazole-4carboxamide (5).

Compound $4(2 \mathrm{mmol})$ and hydrazinium hydroxide $(5 \mathrm{mmol})$ were heated above water bath for $2 \mathrm{~h}$. Cool the mixture then filter the precipitate and finally recrystallize from $\mathrm{EtOH} / \mathrm{DMF}$ (4:1) to give compound 5. Yield 90\%; mp 250-252 ${ }^{\circ} \mathrm{C}$; IR $(\mathrm{KBr}): \mathrm{v} / \mathrm{cm}^{-1}=3412$ $\left(\mathrm{NH}_{2}\right), 3313(\mathrm{NH}), 1637(\mathrm{C}=\mathrm{O}) ;{ }^{1} \mathrm{H}$ NMR (DMSO-d6): $\delta 2.38\left(\mathrm{~s}, 3 \mathrm{H}, \mathrm{CH}_{3}\right), 6.32-7.75(\mathrm{~m}, 8 \mathrm{H}$, ArH and $2 \mathrm{H}$ for $\left.\mathrm{NH}_{2}\right), 9.33(\mathrm{~s}, 1 \mathrm{H}, \mathrm{N}-\mathrm{H}), 11.04(\mathrm{~s}, 1 \mathrm{H}, \mathrm{N}-\mathrm{H}), 12.96(\mathrm{~s}, 1 \mathrm{H}, \mathrm{N}-\mathrm{H}) . \mathrm{MS} \mathrm{m} / z(\%)$ : $366\left(\mathrm{M}^{+}+2,15.43\right), 365\left(\mathrm{M}^{+}+1,28.80\right), 364\left(\mathrm{M}^{+}, 100.00\right), 77$ (10.69), 51 (10.32). Anal. Calced for $\mathrm{C}_{18} \mathrm{H}_{16} \mathrm{~N}_{6} \mathrm{OS}$ (364.43):C, 59.33; H,4.43; N, 23.06\%. Found: C, 59.17; H, 4.51; N, 23.13\%. 
2.4. Synthesis of 5,7-dimethyl-N-(6-methylbenzo[d]thiazol-2-yl)-2(phenylamino)pyrazolo[1,5-a]pyrimidine-3-carboxamide (7).

A mixture of compound 5 ( $0.728 \mathrm{~g}, 2 \mathrm{mmol})$ and an equimolar amount of acetylacetone in glacial acetic acid $(15 \mathrm{~mL})$ was heated under reflux for $1 \mathrm{~h}$. The formed solid product was filtered off, washed with ethanol, dried, and recrystallized from a suitable solvent to give compounds (7). Yellowish white crystals (EtOH : DMF) (2:1); Yield 87\%; mp 290-291 ${ }^{\circ} \mathrm{C}$. IR (KBr): v/cm ${ }^{-1}=3319,3221(2 \mathrm{NH}), 1653(\mathrm{C}=\mathrm{O})$. MS m/z $(\%): 430\left(\mathrm{M}^{+}+2,9.61\right), 428\left(\mathrm{M}^{+}\right.$, 100.00), 412 (15.87), 265 (4.06). Anal. for $\mathrm{C}_{23} \mathrm{H}_{20} \mathrm{~N}_{6} \mathrm{OS}$ (428.51): C, 64.47; H, 4.70; N, 19.61; O, 3.73; S, 7.48 Calcd.: C, 64.47; H, 4.70; N, $19.61 \%$. Found: C, 64.50; H, 4.65; N, $19.53 \%$.

2.5. Synthesis of 5,7-dimethyl-N-(6-methylbenzo[d]thiazol-2-yl)-2(phenylamino)pyrazolo[1,5-a]pyrimidine-3-carboxamide (8).

A mixture of compound $5(0.728 \mathrm{~g}, 2 \mathrm{mmol})$ and an equimolar amount of ethyl acetoacetate in glacial acetic acid $(15 \mathrm{~mL})$ was heated under reflux for $1 \mathrm{~h}$. The formed solid product was filtered off, washed with ethanol, dried and recrystallized from a suitable solvent to give compounds 8. Yellowish white crystals (EtOH : DMF) (2:1); Yield 85\%; mp 295$297^{\circ} \mathrm{C}$. IR (KBr): v/cm ${ }^{-1}=3456(\mathrm{OH}), 1677(\mathrm{C}=\mathrm{O}) .{ }^{1} \mathrm{H}$ NMR (DMSO- $\left.d 6\right): \delta 2.41\left(\mathrm{~s}, 3 \mathrm{H}, \mathrm{CH}_{3}\right)$, $2.42\left(\mathrm{~s}, 3 \mathrm{H}, \mathrm{CH}_{3}\right), 5.80(\mathrm{~s}, \mathrm{H}, \mathrm{CH}), 6.95-7.91(\mathrm{~m}, 8 \mathrm{H}, \mathrm{ArH}), 9.58(\mathrm{~s}, 1 \mathrm{H}, \mathrm{N}-\mathrm{H}), 11.48(\mathrm{~s}, 1 \mathrm{H}$, $\mathrm{OH}), 13.39$ (s, 1H, N-H). MS m/z (\%): $432\left(\mathrm{M}^{+}+2,2.11\right), 431\left(\mathrm{M}^{+}+1,5.94\right), 430\left(\mathrm{M}^{+}, 25.04\right)$, 240 (14.14), 190 (100.00), 164 (63.75), 77 (70.89), 69 (49.49), 51 (44.79). Anal. for $\mathrm{C}_{22} \mathrm{H}_{18} \mathrm{~N}_{6} \mathrm{O}_{2} \mathrm{~S}$ (430.49): C, 61.38; H, 4.21; N, 19.52; O, 7.43; S, 7.45 Calcd.: C, 61.38; H, 4.21; $\mathrm{N}, 19.52 \%$. Found: C, 61.31; H, 4.19; N, $19.48 \%$.

2.6. Synthesis of 5-amino-6-cyano-7-(4-methoxyphenyl)-N-(6-methylbenzo[d]thiazol-2-yl)-2(phenylamino)pyrazolo[1,5-a]pyrimidine-3-carboxamide (11).

A suspension of $5(0.728 \mathrm{~g}, 2 \mathrm{mmol})$ and 2-(4-methoxybenzylidene)malononitrile ( $2 \mathrm{mmol})$ in absolute ethanol was treated with piperidine $(1 \mathrm{ml})$. The reaction mixture was refluxed for $3 \mathrm{~h}$. The solvent was then evaporated in vacuo. The remaining solid was triturated with ice water and acidified with concentrated $\mathrm{HCl}$. The product was collected by filteration and finally recrystallised from the appropriate solvent to afford the pyrazolopyrimidine derivatives 11. Yellow powder; yield $88 \%$; mp above $300^{\circ} \mathrm{C}$. IR $(\mathrm{KBr}): \mathrm{v} / \mathrm{cm}^{-1}=3438\left(\mathrm{NH}_{2}\right)$, 3315, $3279(2 \mathrm{NH}), 2219(\mathrm{C} \equiv \mathrm{N}), 1648(\mathrm{C}=\mathrm{O}) .{ }^{1} \mathrm{H}$ NMR (DMSO-d6): $\delta 2.41\left(\mathrm{~s}, 3 \mathrm{H}, \mathrm{CH}_{3}\right), 3.92$ (s, 3H, CH3), 7.01-7.97 (m, 12H, ArH), 9.04 (s, 1H, N-H), 9.19 (s, 2H, NH 2$), 11.39$ (s, 1H, NH). MS $m / z$ (\%): $548\left(\mathrm{M}^{+}+2,9.82\right), 547\left(\mathrm{M}^{+}+1,30.81\right), 546\left(\mathrm{M}^{+}, 53.24\right), 428$ (31.07), 412 (100.00), 383 (30.70), 265 (53.63), 164 (38.17), 120 (38.99), 77 (89.22), 65 (45.14). Anal. for $\mathrm{C}_{29} \mathrm{H}_{22} \mathrm{~N}_{8} \mathrm{O}_{2} \mathrm{~S}$ (546.61): C, 63.72; H, 4.06; N, 20.50; Calcd.: C, 63.72; H, 4.06; N, $20.50 \%$. Found: C, 63.80; H, 3.95; N, $20.41 \%$.

2.7. Synthesis of 7-hydroxy-N-(6-methylbenzo[d]thiazol-2-yl)-5-oxo-2-(phenylamino)-4,5dihydropyrazolo[1,5-a]pyrimidine-3-carboxamide (12).

A mixture of compound $5(0.728 \mathrm{~g}, 2 \mathrm{mmol})$ and diethyl malonate $(2 \mathrm{mmol})$ in glacial acetic acid $(20 \mathrm{~mL})$ was heated under reflux for 45 minutes. The formed solid product was filtered off, washed with ethanol, dried and recrystallized from mixture of ethanol and DMF (3:1) to give 12 . Yellow crystals; yield $81 \%$; mp 299-300 C. IR $(\mathrm{KBr}): \mathrm{v} / \mathrm{cm}^{-1}=3515(\mathrm{OH})$, 3455, 3277, 3215 (3NH), 1677, 1638 (2C=O). ${ }^{1} \mathrm{H}$ NMR (DMSO-d6): $\delta 2.40$ (s, 3H, CH ), 5.79 
(s, H, CH), 6.94-7.91 (m, 8H, ArCH), 9.55 (s, 1H, NH), 11.47 (s, 1H, N-H), 13.37 (s, 1H, NH). MS m/z (\%): 432 ( $\left.\mathrm{M}^{+}, 3.07\right), 430$ (18.17), 412 (100.00), 164 (2.62), 77 (6.82), 65 (3.42), 51 (4.48). Anal. for $\mathrm{C}_{21} \mathrm{H}_{16} \mathrm{~N}_{6} \mathrm{O}_{3} \mathrm{~S}$ (432.46): Calcd.: C, 58.32; H, 3.73; N, $19.43 \%$. Found: $\mathrm{C}$, $58.24 ; \mathrm{H}, 3.68 ; \mathrm{N}, 19.35 \%$.

\section{Results and Discussion}

\subsection{Chemistry.}

Cyanoacylation of 2-aminobenzothiazole derivative 1 with 1-cyano-acetyl-3,5 dimethylpyrazole in dry toluene afforded 2-cyano-N-(6-methylbenzo[ $d]$ thiazol-2-yl) acetamide 2. IR spectrum of 2 displayed bands at 3199, 2262, and $1706 \mathrm{~cm}^{-1}$ attributable to $\mathrm{NH}, \mathrm{CN}$, and $\mathrm{CO}$ groups. ${ }^{1} \mathrm{H}-\mathrm{NMR}$ displayed a singlet signal at $\delta 4.11 \mathrm{ppm}$ for methylene protons.

The reaction of active methylene with PhNCS in the basic medium was investigated to synthesize pyrazole ring moiety [28]. The base-catalyzed reaction of the 2 with PhNCS in dry dimethylformamide gave the nonisolable intermediate 3 . Treatment of 3 with methyl iodide afforded 4. Its ${ }^{1} \mathrm{H}-\mathrm{NMR}$ showed a characteristic signal at $\delta 2.23$ referred to $\mathrm{SCH}_{3}$ protons. The reaction of 4 with an excess of hydrazine hydrate afforded aminopyrazole 5 (Scheme 1). Its ${ }^{1} \mathrm{H}$ NMR spectrum displayed multiplet signals at $\delta 6.32-7.75 \mathrm{ppm}$ region due to aromatic protons and $\mathrm{NH}_{2}$ protons and three singlet signals at $\delta 9.33,11.04$, and $12.96 \mathrm{ppm}$ for $3 \mathrm{NH}$ protons.

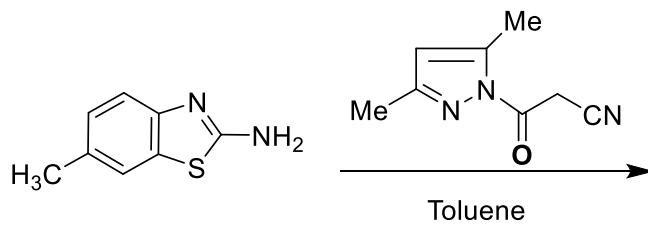

(1)<smiles>Cc1ccc2nc(NC(=O)CC#N)sc2c1</smiles>
PhNCS DMF/KOH<smiles>Cc1ccc2nc(NC(=O)/C(C#N)=C(/[Se])Nc3ccccc3)sc2c1</smiles>

(3)<smiles>[3H][V]</smiles><smiles>Cc1ccc2nc(NC(=O)c3c(Nc4ccccc4)n[nH]c3N)sc2c1</smiles><smiles>CCC(N)(N)CCNC(=O)C(C#N)=C(Nc1ccccc1)Nc1nc2ccc(C)cc2s1</smiles>

Scheme 1. Synthesis of aminopyrazole derivative 5.

5-Aminopyrazoles are versatile reagents and have been extensively used as synthetic starting materials to synthesize several poly-substituted fused pyrazoles of potential biological 
activity [29-31]. It was of interest to study the reactivity of 5-aminopyrazole 5 towards a variety of chemical reagents. The general literature procedure [32-34] for the synthesis of pyrazolo [1,5-a]pyrimidines involves cyclocondensation of aminopyrazoles with reagents having 1,3electrophilic centers such as $\beta$-diketones. Thus, cyclocondensation reaction of compound 5 with acetylacetone and/or ethyl acetoacetate in boiling acetic acid produced a single product formulated as pyrazolo[1,5-a]pyrimidine derivative 7 and 8, respectively (Scheme 2). The IR spectrum of 7 displayed absorption bands at 3319, 3221, and $1653 \mathrm{~cm}^{-1}$ due to two $\mathrm{NH}$ and amidic $\mathrm{CO}$ function groups. The mass spectrum showed a molecular ion peak at $\mathrm{m} / \mathrm{z}=428$ $\left(\mathrm{M}^{+}, 100.00\right)$ corresponding to molecular formula $\mathrm{C}_{23} \mathrm{H}_{20} \mathrm{~N}_{6} \mathrm{OS}$.

Also, IR spectrum of 8 displayed an absorption band at $3456 \mathrm{~cm}^{-1}$ for $\mathrm{OH}$ group and $1677 \mathrm{~cm}^{-1}$ due to the amidic CO function group. The ${ }^{1} \mathrm{H}$ NMR spectrum (DMSO $-d 6$ ) exhibited the lack of signal assignable to $\mathrm{NH}_{2}$ and the presence of two singlet signals at $\delta 2.41$ and 2.42 ppm assignable to two methyl groups, besides singlet signal at $\delta 5.80 \mathrm{ppm}$ assignable to $\mathrm{CH}$ proton of the pyrimidine ring. In addition to multiplet signals at $\delta 6.95-7.91 \mathrm{ppm}$ region owing to aromatic protons, and three singlet signals at $\delta 9.58,11.48$, and $13.39 \mathrm{ppm} \mathrm{NH}, \mathrm{OH}$ and NH protons, respectively. The mass spectrum showed a molecular ion peak at $\mathrm{m} / \mathrm{z}=430$, correspondings to molecular formula $\mathrm{C}_{22} \mathrm{H}_{18} \mathrm{~N}_{6} \mathrm{O}_{2} \mathrm{~S}$.<smiles>Cc1ccc2nc(NC(=O)c3c(N)n[nH]c3Nc3ccccc3)sc2c1</smiles>

(5)<smiles>CCOC(=O)CC(C)=O</smiles>

(8)
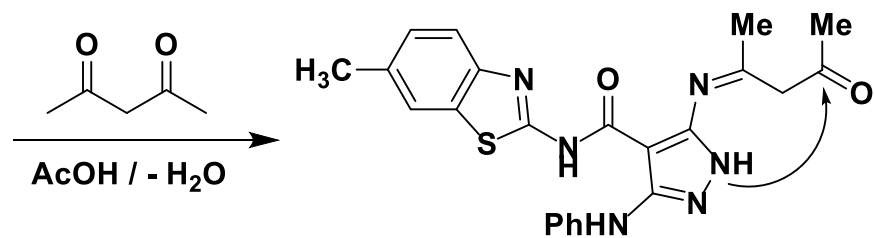

(6)

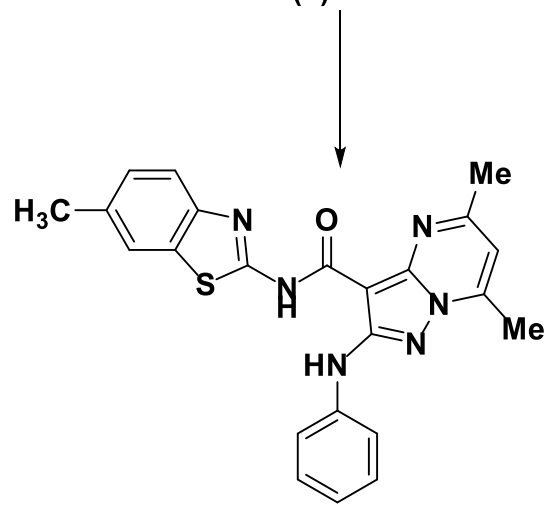

Scheme 2. Synthesis of pyrazolo pyrimidine derivatives 7 and 8 .

Another approach for obtaining pyrazolo[1,5- $a$ ]pyrimidine compounds is the reaction of 5-aminopyrazole with arylidines of malononitrile. Thus, compound 5 was treated with 2-(4methoxybenzylidene)malononitrile in ethanol containing a catalytic amount of piperdine to give the target 5-amino-6-cyano-7-(4-methoxyphenyl)-N-(6-methyl-1H-inden-2-yl)-2(phenylamino)pyrazolo[1,5-a]pyrimidine-3-carboxamide (11) (Scheme 3). IR spectrum of 11 displayed absorption bands at 3438, 3315, 3279, 2219, and $1648 \mathrm{~cm}^{-1}$ due to $\mathrm{NH}_{2}, 2 \mathrm{NH}, \mathrm{CN}$, and $\mathrm{CO}$ function groups. The ${ }^{1} \mathrm{H}$ NMR spectrum (DMSO-d6) exhibited the presence of two singlet signals at $\delta 2.41$ and $3.92 \mathrm{ppm}$ assignable to two methyl groups, multiplet signals at $\delta$ 7.01-7.97 ppm region owing to aromatic protons besides three singlet signals at $\delta 9.04,9.19$ and $11.39 \mathrm{ppm}$ due to $\mathrm{NH}, \mathrm{NH}_{2}$ and $\mathrm{NH}$ protons, respectively. The mass spectrum showed a 
molecular ion peak at $m / z=546$, correspondings to a molecular formula $\mathrm{C}_{29} \mathrm{H}_{22} \mathrm{~N}_{8} \mathrm{O}_{2} \mathrm{~S}$. The formation of the pyrazolo[1,5-a]pyrimidine 11 may be due to the initial addition of the more basic endocyclic nitrogen atom in the pyrazole ring to the double bond in the arylidine derivative to form the intermediates 9 and 10. These intermediates underwent autoxidation to give pyrazolo[1,5-a]pyrimidine 11 .<smiles>CCOC(=O)/C(C#N)=C\c1ccc(OC)cc1</smiles><smiles></smiles>

Scheme 3. Synthesis of 5-amino-6-cyano-7-(4-methoxyphenyl)-N-(6-methylbenzo[d]thiazol-2-yl)-2(phenylamino)pyrazolo[1,5-a]pyrimidine-3-carboxamide (11).

Moreover, the reaction of 5-aminopyrazole 5 with diethyl malonate gave 7-hydroxy- $N$ (6-methylbenzo[d]thiazol-2-yl)-5-oxo-2-(phenylamino)-4,5-dihydropyrazolo[1,5

a]pyrimidine-3-carboxamide (12) (Scheme 4). Its IR spectrum displayed absorption bands at $3515,3455,3277,3215,1677$, and $1638 \mathrm{~cm}^{-1}$ due to $\mathrm{OH}$, three $\mathrm{NH}$, and two $\mathrm{CO}$ functions, respectively. The ${ }^{1} \mathrm{H}$ NMR spectrum (DMSO $-d_{6}$ ) exhibited the lack of signal assignable to $\mathrm{NH}_{2}$ and the presence of a sharp singlet signal at $\delta 2.40 \mathrm{ppm}$ corresponding to methyl protons, a sharp singlet signal at $\delta 5.79 \mathrm{ppm}$ assignable to $\mathrm{CH}$ proton besides multiplet signals at $\delta 6.94$ $7.91 \mathrm{ppm}$ region owing to aromatic protons, and three singlet signals at $\delta 9.55,11.47$ and 13.37 ppm due to three NH protons. The mass spectrum showed a molecular ion peak at $\mathrm{m} / \mathrm{z}=432$, correspondings to molecular formula $\mathrm{C}_{21} \mathrm{H}_{16} \mathrm{~N}_{6} \mathrm{O}_{3} \mathrm{~S}$.

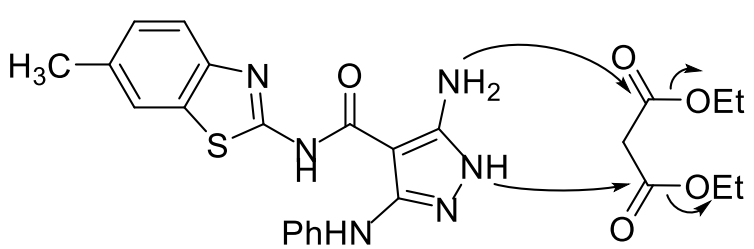

(5)<smiles></smiles>

(12)

Scheme 4. Synthesis of 7-hydroxy-N-(6-methylbenzo[d]thiazol-2-yl)-5-oxo-2-(phenylamino)-4,5dihydropyrazolo[1,5-a]pyrimidine-3-carboxamide (12). 


\section{Conclusions}

In this article, a simple and efficient method for synthesizing some novel aminopyrazole and pyrazolopyrimidine incorporating the benzothiazole moiety in good yields and high purity was achieved. Our synthesized compounds were elucidated depending on different spectroscopic techniques. Further studies are being conducted to acquire more information about biological activities such as antimicrobial, antioxidant, or antifungals to study quantitative structure-activity relationships (QSAR).

\section{Funding}

This research received no external funding.

\section{Acknowledgments}

This research has no acknowledgment.

\section{Conflicts of Interest}

The authors declare no conflict of interest.

\section{References}

1. Vinogradov, M.G.; Turova, O.V.; Zlotin, S.G. Recent advances in the asymmetric synthesis of pharmacology-relevant nitrogen heterocycles via stereoselective aza-Michael reactions. Organic \& Biomolecular Chemistry 2019, 17, 3670-3708, https://doi.org/10.1039/C8OB03034K.

2. Irfan, A.; Batool, F.; Zahra Naqvi, S.A.; Islam, A.; Osman, S.M.; Nocentini, A.; Alissa, S.A.; Supuran, C.T. Benzothiazole derivatives as anticancer agents. Journal of Enzyme Inhibition and Medicinal Chemistry 2020, 35, 265-279, https://doi.org/10.1080/14756366.2019.1698036.

3. Venugopala, K.N.; Khedr, M.A.; Pillay, M.; Nayak, S.K.; Chandrashekharappa, S.; Aldhubiab, B.E.; Harsha, S.; Attimard, M.; Odhav, B. Benzothiazole analogs as potential anti-TB agents: computational input and molecular dynamics. Journal of Biomolecular Structure and Dynamics 2019, 37, 1830-1842, https://doi.org/10.1080/07391102.2018.1470035.

4. Morsy, M.A.; Ali, E.M.; Kandeel, M.; Venugopala, K.N.; Nair, A.B.; Greish, K.; El-Daly, M. Screening and Molecular Docking of Novel Benzothiazole Derivatives as Potential Antimicrobial Agents. Antibiotics 2020, 9, 221, https://doi.org/10.3390/antibiotics9050221.

5. Jin, Q.; Fu, Z.; Guan, L.; Jiang, H. Syntheses of Benzo[d]Thiazol-2(3H)-One Derivatives and Their Antidepressant and Anticonvulsant Effects. Marine Drugs 2019, 17, 430, https://doi.org/10.3390/md17070430.

6. Asiri, Y.I.; Alsayari, A.; Muhsinah, A.B.; Mabkhot, Y.N.; Hassan, M.Z. Benzothiazoles as potential antiviral agents. Journal of Pharmacy and Pharmacology 2020, 72, 1459-1480, https://doi.org/10.1111/jphp.13331.

7. Tariq, S.; Kamboj, P.; Amir, M. Therapeutic advancement of benzothiazole derivatives in the last decennial period. Archiv der Pharmazie 2019, 352, https://doi.org/10.1002/ardp.201800170.

8. Bhavsar, Z.A.; Acharya, P.T.; Jethava, D.J.; Patel, H.D. Recent advances in development of anthelmintic agents: Synthesis and biological screening. Synthetic Communications 2020, 50, 917-946, https://doi.org/10.1080/00397911.2019.1695276.

9. Djuidje, E.N.; Sciabica, S.; Buzzi, R.; Dissette, V.; Balzarini, J.; Liekens, S.; Serra, E.; Andreotti, E.; Manfredini, S.; Vertuani, S.; Baldisserotto, A. Design, synthesis and evaluation of benzothiazole derivatives as multifunctional agents. Bioorganic Chemistry 2020, 101, https://doi.org/10.1016/j.bioorg.2020.103960.

10. Ugwu, D.I.; Okoro, U.C.; Ukoha, P.O.; Gupta, A.; Okafor, S.N. Novel anti-inflammatory and analgesic agents: synthesis, molecular docking and in vivo studies. Journal of Enzyme Inhibition and Medicinal Chemistry 2018, 33, 405-415, https://doi.org/10.1080/14756366.2018.1426573.

11. Zheng, X.-J.; Li, C.-S.; Cui, M.-Y.; Song, Z.-W.; Bai, X.-Q.; Liang, C.-W.; Wang, H.-Y.; Zhang, T.-Y. Synthesis, biological evaluation of benzothiazole derivatives bearing a 1,3,4-oxadiazole moiety as potential antioxidant and anti-inflammatory agents. Bioorg Med Chem Lett 2020, 30, https://doi.org/10.1016/j.bmcl.2020.127237.

12. Bhutani, R.; Pathak, D.P.; Kapoor, G.; Husain, A.; Iqbal, M.A. Novel hybrids of benzothiazole-1,3,4oxadiazole-4-thiazolidinone: Synthesis, in silico ADME study, molecular docking and in vivo anti-diabetic assessment. Bioorganic Chemistry 2019, 83, 6-19, https://doi.org/10.1016/j.bioorg.2018.10.025. 
13. Cui, K.; He, L.; Zhang, Z.; Zhang, T.; Mu, W.; Liu, F. Evaluation of the efficacy of benzothiazole against the red flour beetle, Tribolium castaneum (Herbst). Pest Management Science 2020, 76, 27262735,https://doi.org/10.1002/ps.5819.

14. Sato, Y.; Sobu, S.; Nakabayashi, K.; Samitsu, S.; Mori, H. Highly Transparent Benzothiazole-Based Block and Random Copolymers with High Refractive Indices by RAFT Polymerization. ACS Applied Polymer Materials 2020, 2, 3205-3214, https://doi.org/10.1021/acsapm.0c00365.

15. Cao, Z.; Qiu, F.; Wang, Q.; Cao, G.; Zhuang, L.; Shen, Q.; Xu, X.; Wang, J.; Chen, Q.; Yang, D. Synthesis of azo benzothiazole polymer and its application of $1 \times 2$ Y-branched and $2 \times 2$ Mach-Zehnder interferometer switch. Optik 2013, 124, 4036-4040, https://doi.org/10.1016/j.ijleo.2012.12.063.

16. Dzulkharnien, N.S.F.; Karim, M.R.; Zahid, N.I.; Rahman, N.M.M.A.; Abdullah, I.; Salleh, N.M. Optical Properties of Azo-Benzothiazole Side Chain Liquid Crystalline Polymers: Effect of Solvents, Substituents and Temperatures. Journal of fluorescence 2019, 29, 1049-1056, https://doi.org/10.1007/s10895-01902418-9.

17. Krishnan, K.G.; Kumar, C.U.; Lim, W.-M.; Mai, C.-W.; Thanikachalam, P.V.; Ramalingan, C. Novel cyanoacetamide integrated phenothiazines: Synthesis, characterization, computational studies and in vitro antioxidant and anticancer evaluations. Journal of Molecular Structure 2020, 1199, https://doi.org/10.1016/j.molstruc.2019.127037.

18. Kong, L.; Huang, R.; He, H.; Fan, Y.; Lin, J.; Yan, S. Multi-component solvent-free cascade reaction of 2cyanoacetamides: regioselective synthesis of pyridin-2-ones bearing quaternary centers. Green Chemistry 2020, 22, 256-264, https://doi.org/10.1039/C9GC03692J.

19. Hamed, E.O.; Assy, M.G.; Shalaby, A.M.; Sayed, R.E. Cyclization of N-benzyl cyanoacetamide: Novel synthesis and biological activity of pyrrole, pyrimidine, and pyran derivatives. Journal of Heterocyclic Chemistry 2020, 57, 1672-1681, https://doi.org/10.1002/jhet.3892.

20. Azzam, R.A.; Elgemeie, G.H.; Osman, R.R. Synthesis of novel pyrido[2,1-b]benzothiazole and Nsubstituted 2-pyridylbenzothiazole derivatives showing remarkable fluorescence and biological activities. Journal of Molecular Structure 2020, 1201, https://doi.org/10.1016/j.molstruc.2019.127194.

21. Abdelall, E.K.A.; Lamie, P.F.; Ahmed, A.K.M.; El-Nahass, E.L.S. COX-1/COX-2 inhibition assays and histopathological study of the new designed anti-inflammatory agent with a pyrazolopyrimidine core. Bioorganic Chemistry 2019, 86, 235-253, https://doi.org/10.1016/j.bioorg.2019.01.031.

22. Bilsland, A.E.; Liu, Y.; Turnbull, A.; Sumpton, D.; Stevenson, K.; Cairney, C.J.; Boyd, S.M.; Roffey, J.; Jenkinson, D.; Keith, W.N. A Novel Pyrazolopyrimidine Ligand of Human PGK1 and Stress Sensor DJ1 Modulates the Shelterin Complex and Telomere Length Regulation. Neoplasia 2019, 21, 893-907, https://doi.org/10.1016/j.neo.2019.07.008.

23. Ghelani, S.M.; Naliapara, Y.T. Design, Multicomponent Synthesis and Characterization of Diversely Substituted Pyrazolo[1,5-a] Pyrimidine Derivatives. Journal of Heterocyclic Chemistry 2016, 53, 18431851, https://doi.org/10.1002/jhet.2496.

24. Demir Özkay, Ü.; Üçel, U.; Turan, N.; Can, Ö.D. Antinociceptive and Anxiolytic-Like Effects of Some Compounds Carrying Benzothiazole Ring. Kocatepe Veterinary Journal 2019, 12, 122-129, https://doi.org/10.30607/kvj.524391.

25. Naqvi, A.A.T.; Jairajpuri, D.S.; Noman, O.M.A.; Hussain, A.; Islam, A.; Ahmad, F.; Alajmi, M.F.; Hassan, M.I. Evaluation of pyrazolopyrimidine derivatives as microtubule affinity regulating kinase 4 inhibitors: Towards therapeutic management of Alzheimer's disease. Journal of Biomolecular Structure and Dynamics 2020, 38, 3892-3907, https://doi.org/10.1080/07391102.2019.1666745.

26. Tian, Y.; Du, D.; Rai, D.; Wang, L.; Liu, H.; Zhan, P.; De Clercq, E.; Pannecouque, C.; Liu, X. Fused heterocyclic compounds bearing bridgehead nitrogen as potent HIV-1 NNRTIs. Part 1: Design, synthesis and biological evaluation of novel 5,7-disubstituted pyrazolo[1,5-a]pyrimidine derivatives. Bioorganic \& Medicinal Chemistry 2014, 22, 2052-2059, https://doi.org/10.1016/j.bmc.2014.02.029.

27. Abdelhamid, A.O.; Gomha, S.M.; El-Enany, W.A.M.A. Efficient Synthesis and Antimicrobial Evaluation of New Azolopyrimidines-Bearing Pyrazole Moiety. Journal of Heterocyclic Chemistry 2019, 56, 2487 2493, https://doi.org/10.1002/jhet.3638.

28. Metwally, M.A.; Keshk, E.M.; Fekry, A.; Etman, H.A. Synthesis and reactions of 2-cyano-2-(5-oxo-3phenyl-thiazolidin-2-ylidene)-acetamides. Journal of Chemical Research 2004, 2004, 602-604, https://doi.org/10.3184/0308234042430322.

29. Ali, G.M.E.; Ibrahim, D.A.; Elmetwali, A.M.; Ismail, N.S.M. Design, synthesis and biological evaluation of certain CDK2 inhibitors based on pyrazole and pyrazolo[1,5-a] pyrimidine scaffold with apoptotic activity. Bioorganic Chemistry 2019, 86, 1-14, https://doi.org/10.1016/j.bioorg.2019.01.008.

30. Shu, S.; Dai, A.; Wang, J.; Wang, B.; Feng, Y.; Li, J.; Cai, X.; Yang, D.; Ma, D.; Wang, M.-W.; Liu, H. A novel series of 4-methyl substituted pyrazole derivatives as potent glucagon receptor antagonists: Design, synthesis and evaluation of biological activities. Bioorganic \& Medicinal Chemistry 2018, 26, 1896-1908, https://doi.org/10.1016/j.bmc.2018.02.036.

31. Galal, S.A.; Abdelsamie, A.S.; Shouman, S.A.; Attia, Y.M.; Ali, H.I.; Tabll, A.; El-Shenawy, R.; El Abd, Y.S.; Ali, M.M.; Mahmoud, A.E.; Abdel-Halim, A.H.; Fyiad, A.A.; Girgis, A.S.; El-Diwani, H.I. Part I: Design, synthesis and biological evaluation of novel pyrazole-benzimidazole conjugates as checkpoint 
kinase 2 (Chk2) inhibitors with studying their activities alone and in combination with genotoxic drugs. European Journal of Medicinal Chemistry 2017, https://doi.org/10.1016/j.ejmech.2017.03.090.

32. Attia, M.H.; Elrazaz, E.Z.; El-Emam, S.Z.; Taher, A.T.; Abdel-Aziz, H.A.; Abouzid, K.A.M. Synthesis and in-vitro anti-proliferative evaluation of some pyrazolo[1,5-a]pyrimidines as novel larotrectinib analogs. Bioorganic Chemistry 2020, 94, https://doi.org/10.1016/j.bioorg.2019.103458.

33. Singleton, J.D.; Dass, R.; Neubert, N.R.; Smith, R.M.; Webber, Z.; Hansen, M.D.H.; Peterson, M.A. Synthesis and biological evaluation of novel pyrazolo[1,5-a]pyrimidines: Discovery of a selective inhibitor of JAK1 JH2 pseudokinase and VPS34. Bioorg Med Chem Lett 2020, 30, https://doi.org/10.1016/j.bmcl.2019.126813.

34. Zhao, M.; Ren, H.; Chang, J.; Zhang, D.; Yang, Y.; He, Y.; Qi, C.; Zhang, H. Design and synthesis of novel pyrazolo[1,5-a]pyrimidine derivatives bearing nitrogen mustard moiety and evaluation of their antitumor activity in vitro and in vivo. European Journal of Medicinal Chemistry 2016, 119, 183-196, https://doi.org/10.1016/j.ejmech.2016.04.068. 